\title{
MOMENTOS BORBOLETA
}

\author{
Rovana Chaves nasceu em Palmeira das Missões (RS) em 1981. Reside nesta mesma cidade. É professora da rede Estadual de \\ Ensino, Mestre em Letras e acadêmica do curso de Direito. \\ E-mail: rovana.c@gmail.com
}

Esta história acontece no início dos anos oitenta, numa cidade do interior do Brasil. Não vou mencionar o nome da cidade porque pode ficar a cargo de cada leitor imaginá-la. Falo aqui sobre uma mulher aparentemente sem voz e ao mesmo tempo dona de uma inocência ímpar. Falo de Amélia. Para tanto, é interessante fazer uma retrospectiva de como fora sua infância.

Desde pequena identificada por sua doçura e obediência. Seus pais não tiveram trabalho algum em sua criação, visto que ela permitia-se seguir as regras que lhes eram apresentadas sem questionar. Permitia-se simplesmente obedecer. Possuía um medo enorme de possíveis punições que poderia sofrer se acaso não tivesse um comportamento condizente com as proibições, limitações e obrigações. Por exemplo, se lhe falassem que lhe faria mal ir num final de tarde andar de bicicleta na praça em frente à sua casa, certamente Amélia não seria vista por lá. Se ela fosse, receberia uma punição em forma de castigo, que poderia durar dias ou semanas; até meses. E caso contrário, sua obediência lhe traria um prêmio, como balas de morango - as suas favoritas.

Amélia cresceu assim. E antes de morrer, sua mãe vivia lhe dizendo para ser obediente, pois só assim teria uma vida pura e conseguiria um bom casamento e seria feliz nele - visto que chegaria o dia em que muitas mulheres seriam solteiras e com idade avançada, o que era algo muito ruim para a família e para a mulher. Ser solteira pela vida toda, não era algo que agradasse as conveniências sociais. A partir do instante em que ficaram somente ela e seu pai, este mesmo conselho não deixou de acompanhar nossa protagonista diariamente, visto que seu pai relembrava sempre tais palavras.

O comportamento inocente de Amélia só evidenciava ainda mais sua carência afetiva. Mesmo sendo filha única, seus pais não the mimaram muito. Receber um afago no cabelo era algo raro para a garota. Quando isso acontecia, ela chegava a ficar com o corpo dormente de não se mexer, com medo não mais receber o carinho se movesse um de seus dedos, ou se respirasse mais profundamente. Quando ouvia sobre o casamento, pensava que talvez teria mais atenção, mais carinho. E que conforme fosse melhorando seu comportamento acabaria por receber ainda mais afeto, e assim por diante. Amélia achava que isso poderia ser a felicidade do casamento e da vida. Concluía que se ela não tivera nada disso até aquele momento, então ainda não sabia o que era felicidade. Só a conheceria quando se casasse, e estava ansiosa por este momento.

\footnotetext{
Revista Escrita

Rua M arquês de São Vicente, 225 Gávea/RJ CEP 22453-900 Brasil

Ano 2011. Número 13. ISSN 1679-6888.

escrita@puc-rio.br
} 
Quando tinha 18 anos, seu pai a chamou para uma conversa fora daquelas cotidianas. Ele havia conhecido um rapaz chamado Everaldo, muito bem apresentável, embora suas feições às vezes demonstrassem dureza. Disse que poderia ser um bom marido para Amélia. Então, o chamou para jantar com ambos na semana seguinte. O casal conversava pouco, ainda mais sempre na presença do pai da moça. Só foram ficar sozinhos pela primeira vez, após seis meses de namoro, quando enfim foram tomar um sorvete juntos no início da noite. Foi quando então, Amélia fez um pedido ao seu namorado:

- Everaldo, posso fazer um pedido?

- Claro Amélia, se eu souber e puder, vou atender. O que é? - e comeu uma colher bem cheia de sorvete, acomodando-se melhor no banco da sorveteria.

- Você podia me beijar, assim, como aquele beijo que apareceu ontem, na última novela da noite? Ele parecia ser tão apaixonado! - sorriu, e fez um biquinho para aguardar o beijo.

- Não! O que tinha no seu sorvete? Está maluca? Aqui não é lugar para isso, e moça direita não sai fazendo pedidos assim! Não te falaram isso, não?

- Hmm... E quando teremos um beijo assim? Quando uma mulher direita como eu vai ganhar um beijo daqueles sem precisar pedir, e ele não vai ser feio?

- Ah, Amélia! Por favor! Beijos assim podem ocorrer e talvez, depois do casamento! E chega deste assunto. Não estamos felizes assim? Então? Por que estragar?

- É, se você diz, então, estamos felizes assim. E a nossa felicidade vai crescer ainda mais quando nos casarmos. Vamos casar, não vamos? - disse ela toda esperançosa.

- Se você se comportar bem, vamos sim!

É oportuno mencionar que Everaldo tinha uma loja, e não era muito bom para lidar com números. Tinha dificuldade em manter funcionários por muito tempo, em virtude de seu gênio ser um pouco... Forte. E o que mais o encantou em Amélia (se é que pode-se dizer assim), foi o fato de seu pai ter lhe dito que ela era ótima com números. Havia pensado então, em se casar com ela, e fazê-la ajudar na contabilidade da loja. E desse modo, não teria mais problema algum com funcionários mal agradecidos - segundo Everaldo. Afinal, ele sempre tinha razão. Amor? Afeto? Nunca tive certeza de que Everaldo sentia por Amélia.

Casaram-se um ano depois. Amélia não cabia em si de tanta nostalgia! Estava ansiosa por conhecer a verdadeira felicidade! Em seus momentos borboleta, desde pequena, voava em meio a pensamentos e imaginações sobre a felicidade, e agora teria a oportunidade de sentir na pele se era tudo como sempre imaginou. Seus momentos borboleta eram um segredo dela. Ninguém sabia. Estes pequenos instantes tinham este Revista Escrita Rua M arquês de São Vicente, 225 Gávea/RJ CEP 22453-900 Brasil 
nome pelo fato de Amélia adorar borboletas por serem lindas, coloridas, e ao mesmo tempo poderem ir a vários lugares de forma delicada, com a leveza da brisa do vento.

Com o passar do tempo, Amélia foi ficando cada vez melhor com a contabilidade da loja do esposo. Como recompensa, a cada final de mês, ela não recebia salário, sendo que era a esposa do dono. Então, segundo Everaldo, pra quê salário se era ele quem mantinha a casa? Ele a presenteava com moedas e dinheiros que já não estavam mais circulando no mercado. Dizia à pobre coitada que eram muito melhores do que dinheiros atuais porque eram dotados de um valor sentimental muito grande para ele, assim como ela. Claro que ele a valorizava, pois ela conservava casa e loja sempre limpas, em ordem, e ainda por cima, a contabilidade em dia, recebendo Everaldo lucro por lucro!

Amélia sequer discutia. Ficava olhando e identificando os desenhos nas moedas e notas antigas. As guardava sempre em uma caixa, embaixo de sua cama. Chegou um tempo que ela havia enchido uma caixa inteirinha de notas e moedas velhas. Pensava, pensava e pensava... "como meu marido encontra tanto dinheiro velho?" Mas não podia perder tempo pensando na resposta, tinha muitas coisas a fazer. Respondendo aos pensamentos dela, também não faço a menor ideia de como ele conseguia estes "presentes" a ela.

Passaram-se mais de quinze anos, e o casamento deles seguia assim, sem maiores surpresas. Sempre Everaldo dizendo a Amélia: "Nossa! Como você é eficiente Amélia!" Mas ela sequer havia ouvido um "Eu te amo", "não posso viver sem ti" como nas novelas e romances que lia. E a respeito daquele beijo... poucos aconteceram como aquele durante o casamento. E sempre que aconteciam, após beijá-la, Everaldo saía limpando a boca. Ela não questionava, mas pensava que podia ser pelo fato de ele ser um pouco duro, e não se entregar aos sentimentos. Afinal, ela o amava! Tinha de amálo! Ele mostrou a ela como era a felicidade do casamento! E isso ela reconhecia sempre.

Aos poucos, Amélia foi percebendo que seu sentimento de tristeza só aumentava no coração, mas não entendia o motivo. Afinal, tinha um casamento feliz, fazia contas no que ela era ótima -, tinha uma casa. Mas ao mesmo tempo, os momentos borboleta foram ficando ainda mais constantes. $\mathrm{O}$ fato de ela ler romances e ver novelas a levava em situações imaginárias que muitas vezes eram melhores do que a realidade em que vivia. Logo sentia culpa. Culpa por parecer ingrata, preferindo a imaginação do que a realidade feliz que tinha. Mas... Se ela tinha a felicidade na vida real, o que ela tinha na imaginação? Ela não sabia o nome, mas sabia que era uma explosão de sentimentos bons que pareciam fazer o coração arrebentar em mil pedaços, por ser tão pequeno para guardar tantas coisas boas.

E o casamento passando... E ela sempre dizendo ao marido o quanto o amava, mesmo que não ouvisse o mesmo dele. Então, Amélia percebeu que muitas vezes o que 
não é falado, vale mais do que aquilo que é. Ela dizia que sentia amor pelo marido, porque seu pai lhe dizia que devia sentir, afinal, ele era seu companheiro! Ela estava casada e não era solteirona como a maioria de suas colegas de infância! Deveria ser grata a Everaldo! Então, dizer "eu te amo", talvez fosse a maneira mais adequada de mostrar gratidão.

Com o passar do tempo, e Amélia em seus quarenta e oito anos, se sentia cansada daquela vida. Gostaria de ser uma guerreira que fizesse algo de real, e que seu nome fosse ouvido aos quatro cantos como uma mulher diferente! Mas diferente de quê? Se os únicos tipos de mulheres que ela conhecia eram as solteironas infelizes ou as casadas felizes como ela? Isso matutou por muito tempo em sua cabeça. Nossa protagonista às vezes se perguntava quem ela era neste mundo, nesta realidade que vivia. Gostaria de se conhecer, e além disso, queria conhecer o mundo. Mas se persistisse no comportamento que vinha mantendo por todo este tempo... Talvez nunca conheceria nada... E nem se conheceria. Precisava fazer alguma coisa.

Foi então, que simplesmente pegou sua bolsa, pela manhã, como um dia normal de fechamento de contas do mês na loja, e saiu pelo portão de sua casa. Mas não era uma manhã comum - pelo menos não para ela. O que ninguém sabia, é que Amélia desta vez, não seguiria as regras. E o que ninguém imaginava, é que há um bom tempo ela não vinha seguindo as normas ensinadas, e tudo em segredo. Lembra-se das recompensas antigas dadas pelo marido à ela? Pois é... Amélia as guardou até encher duas caixas. Depois, vendeu-as a um colecionador que estava comprando dinheiro antigo para abrir um museu sobre a história da moeda brasileira. Um museu para o município visitar. Com isso, nossa personagem conseguiu uma boa quantia de dinheiro corrente.

Com apenas o dinheiro na bolsa, e roupas que dessem para um ou dois dias, naquela manhã de segunda-feira, Amélia em vez de ir para a loja, como de costume, tomou outro caminho e foi até a parada de ônibus, na saída da cidade. Ela sabia que os ônibus de empresas que por ali passavam iam para lugares diferentes. Qual ela pegaria? Nem ela sabia. Sabia apenas que queria sair dali. Que queria conhecer outras realidades. Que queria se conhecer. E faria isso. A partir do momento em que colocasse o pé no ônibus.

O sentimento de culpa de repente foi embora nas asas da borboleta que a acompanhou por vários momentos em sua imaginação. Não sentia culpa de estar saindo de casa para buscar outro caminho. Não sentia culpa por violar esta regra. Mas uma certeza ela sabia: O sentimento que a acompanhava no começo dessa nova jornada era diferente de tudo que já sentira. Tinha a ideia de que, talvez o que havia pensado ser a felicidade até aquele instante, poderia não ser a felicidade. Será então, que a felicidade era este sentimento novo? Ela não sabia, mas tentaria descobrir... 

Ano 2011. Número 13. ISSN 1679-6888.

escrita@puc-rio.br 